\title{
Electrochemical detection of anticancer drug lumazine and DNA interaction by using carbon nanotube modified electrodes
}

\author{
Hakan KARADENIZ ${ }^{1 *}$ (D) , Ece EKSIN 1 (D), Arzum ERDEM $1 * *$ (D) \\ 1 Faculty of Pharmacy, Analytical Chemistry Department, Ege University, 35100, Bornova, İzmir, TURKEY \\ * Corresponding Author. E-mail: hakan.karadeniz@ege.edu.tr, hakankaradeniz@gmail.com (H.K.); Tel. +90-232-311 \\ 2508. \\ ** Co-corresponding Author. E-mail: arzum.erdem@ege.edu.tr, arzume@hotmail.com (A.E); Tel. +90-232-311 51 31.
}

Received: 26 October 2018/ Revised: 09 April 2019 / Accepted: 13 April 2019

ABSTRACT: The interaction of lumazine (LMZ) with dsDNA was investigated with differential pulse voltammetry (DPV) and electrochemical impedance spectroscopy (EIS) by using disposable carbon nanotubes-modified pencil graphite electrode (CNTs-PGE). The passive adsorption process was used to modify the electrode surface by CNTs and then dsDNA was immobilized onto the modified PGEs. The performance of CNT-PGEs was studied by examining the optimum analytical conditions with DPV and then impedance method was performed to characterize the modification of CNTs onto the electrode surface.

KEYWORDS: Biosensor; carbon nanotubes; electrochemistry; lumazine.

\section{INTRODUCTION}

The usage of nucleic acid layers combined with electrochemical or optical transducers produce a new kind of affinity biosensors for the detection of molecular interactions between double stranded DNA (dsDNA) and the target pollutants or drugs for screening of these compounds [1-4]. As a result of these applications, there has been a growing interest in the usage of these biosensors in the electrochemical investigation of interactions between anticancer drugs and DNA [5-14] by using the advantages of electrochemical methods such as rapid, simple and low-cost point-of-care detection. For the electrochemical detection of the interactions between drug and DNA, the changes at oxidation peak current of the drug or the electroactive DNA bases were observed. In the study of Karadeniz et al. [6] the electrochemical detection of the interaction between mitomycin C (MC) and double-stranded DNA (dsDNA) in microemulsion phase was performed by using differential pulse voltammetry (DPV) in combination with a disposable sensor, pencil graphite electrode (PGE). Wang et al. [7] have shown the interaction of anthracycline antibiotic and antitumor drug daunomycin (DM) with dsDNA studied in solution and at the electrode surface by means of cyclic voltammetry and particularly by consantcurrent chronopotentiometric stripping analysis (CPSA) with carbon paste electrodes (CPE). Brett et al. [10] reported a procedure for the determination of the interaction between anthraquinone drug, mitoxantrone (MTX) and dsDNA or ssDNA at high concentration levels. The interaction was studied in aqueous medium or on electrode surface by using glassy carbon electrode (GCE) in connection with using square-wave voltammetry (SWV) and differential pulse voltammetry (DPV). Ribeiro et al. [12] described a voltammetric method based on the ion transfer at a water/oil interface for the electrochemical study of the interaction between high molecular weight dsDNA and two molecules of biological interest: the anthracycline drug daunorubicin (DNR) and the neurotransmitter dopamine (DA) using DPV technique. Shervedani et al. [13] reported the immobilization of methotrexate (MTX) anticancer drug onto the graphene surface and its interactions with ctDNA and 4T1 cancer cells by using surface analysis techniques and electrochemical methods. Erdem et al. [14] used the DNA-modified CPE in combination with CV and DPV to investigate the interaction of EPR with dsDNA and ssDNA and observed the changes in the EPR signals caused by the intercalation of EPR into dsDNA.

How to cite this article: Karadeniz $\mathrm{H}$, Eksin E, Erdem A. Electrochemical detection of anticancer drug lumazine and DNA interaction by using carbon nanotube modified electrodes. J Res Pharm. 2019; 23(4): 682-688. 
The discovery of carbon nanotubes (CNTs) has become the subject of intense investigation because of their remarkable properties like electrical, chemical and structural properties $[15,16]$. Functionalized CNTs are used in some applications in the field of electroanalytical chemistry, medicinal chemistry, materials science and technology $[17,18]$ It is known that the CNTs enhance the electron transfer rate of many redox reactions [19]. In sensor technology, there has been an attractive interest for the modification of transducers with CNTs. Because of some advantages such as high surface area, fast heterogeneous electron transfer and long-range electron transfer, the modification of electrodes with CNTs played an important role in DNA sensing $[15,20-$ 25].

Modification of carbon electrodes is particularly easy and can be achieved either through physical adsorption of the modifier onto the carbon surface or by covalent attachment of the modifier [26].

Lumazine (pteridine-2,4(1H,3H)-dione) belongs to a group of pteridine compounds which are widespread in biological systems including cells in living bodies. A lumazine derivative, 6,7-dimethyl-8- ribityllumazine, is the biosynthetic precursor of riboflavin (vitamin B2) [27]. Some lumazine derivatives are natural products from the metabolic degradation of pterins [28]. The capability of pterins to act as enzyme cofactors involved in hydroxylation depends on their oxidation/reduction states and on their overall redox chemistry [29]. Study of a wide variety of pterin derivatives including lumazine and xanthopterin showed that the pterins coordinated to metals appear to be good electron sources for metalloenzyme systems that require multielectron redox processes [30]. Lumazine can inhibit the growth of Methanobacterium thermoautotrophicum and Methanococcus voltae [31], thus being an important antibacterial substance. Many scientists presented the electrochemical behavior of LMZ by using voltammetry [32-35].

The aim of this study is to develope single-walled carbon nanotubes (SWCNT) modified disposable graphite electrodes (SWCNT-PGEs) for the electrochemical detection of biomolecular interactions based on the higher signal enhancement in comparison to bare disposable pencil graphite electrodes (PGEs). There have not yet been any reports in the literature for the detection of interaction between LMZ and DNA by using SWCNT modified PGEs. The easy surface modification of disposable graphite electrodes with carbon nanotubes was performed by passive adsorption, and DNA was then immobilized onto the SWCNT-PGEs by hydrogen bond formation between the amine groups of dsDNA and the carboxyl groups of CNTs. The reproducible detection of DNA represents a very attractive approach for the sensitive detection of interaction between LMZ and dsDNA. Voltammetric results were complemented with electrochemical impedance spectroscopy (EIS), that was also used to characterize the successful construction of carbon nanotubes modification onto the surface of PGEs.

\section{RESULTS AND DISCUSSION}

The surface morphologies of unmodified PGE and CNT modified PGE were monitored successfully in the previous study of the authors [36] by using scanning electron microscopy (SEM) in various magnitudes. The optimum experimental conditions for SWCNT-PGE in the detection of anticancer drug-DNA interaction, were determined in the study of Erdem et al. [36]. In the study of Erdem et al. [36] Daunorubicin (DNR) was chosen as a target compound that interacts with double stranded DNA by intercalation. The anthracycline moiety of DNR can intercalate between the stacked base pairs of native DNA, and the sugar-3-amino structure of DNR can bind to the major groove of DNA double helix. According to the author's previous study [36], $3000 \mu \mathrm{g} / \mathrm{mL}$ was used as an optimum SWCNT concentration and $1 \mathrm{~h}$ SWCNT immobilization time for unpretreated PGE.

The optimum DNA concentration for the SWCNT-PGE was used as $50 \mu \mathrm{g} / \mathrm{mL}$ similarly to the earlier study [36]. The average guanine oxidation signal (about $1.015 \mathrm{~V}$ ) was measured for $50 \mu \mathrm{g} / \mathrm{mL}$ fish sperm DNA (fsDNA) $2710 \pm 312 \mathrm{nA}$ and $5896 \pm 348 \mathrm{nA}$ for bare and SWCNT modified PGE, respectively (Figure 1). However, more reproducible results with a signal enhancement of $117 \%$ was obtained with SWCNT modified PGE in comparison to bare PGE (Fig. 1B). This increase at the DNA signal for SWCNT-PGE is similar to the result observed at the study Erdem et al. [36] and Yang et al. [37]. 


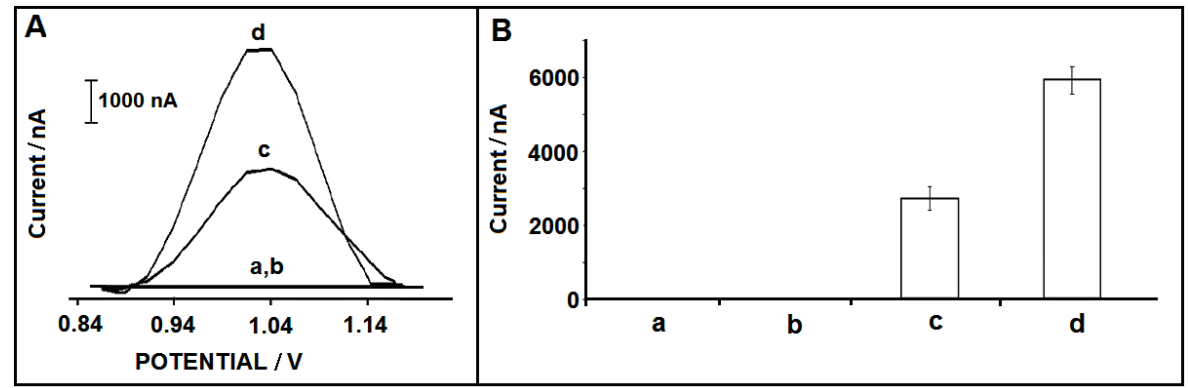

Figure 1. (A) Voltammograms and (B) Histograms representing the control experiment performed in the absence of DNA by using (a) bare PGE, (b) SWCNT-PGE, the oxidation signals of guanine measured by using (c) bare PGE, (d) SWCNT-PGE in the presence of $50.0 \mu \mathrm{g} / \mathrm{mL}$ of dsDNA $(\mathrm{n}=3)$.

The effect of changes at LMZ concentration on the electrode response before and after interaction was studied (Figure 2A and 2B) by using bare and SWCNT modified PGE during the interaction between 50 $\mu \mathrm{g} / \mathrm{mL}$ fsDNA and LMZ in different concentrations such as 2 and $5 \mu \mathrm{g} / \mathrm{mL}$. At both electrodes, there was no LMZ oxidation signal before and after the interaction and the oxidation signal of guanine decreased gradually while the LMZ concentration was $2 \mu \mathrm{g} / \mathrm{mL}$, and then it levelled off. For the interaction between $50 \mu \mathrm{g} / \mathrm{mL}$ fsDNA and $2 \mu \mathrm{g} / \mathrm{mL} \mathrm{LMZ}$, the average guanine oxidation signal was measured $3216 \pm 220 \mathrm{nA}$ and $5128 \pm 420$ $\mathrm{nA}$ for bare and SWCNT modified PGE, respectively, which means there have been $1.8 \%$ and $14.9 \%$ decrease at the guanine oxidation signal after interaction for bare and SWCNT modified PGE, respectively. This decrease at the response obtained using SWCNT modified electrode is similar to the result observed at the study of Karadeniz et al. [6].

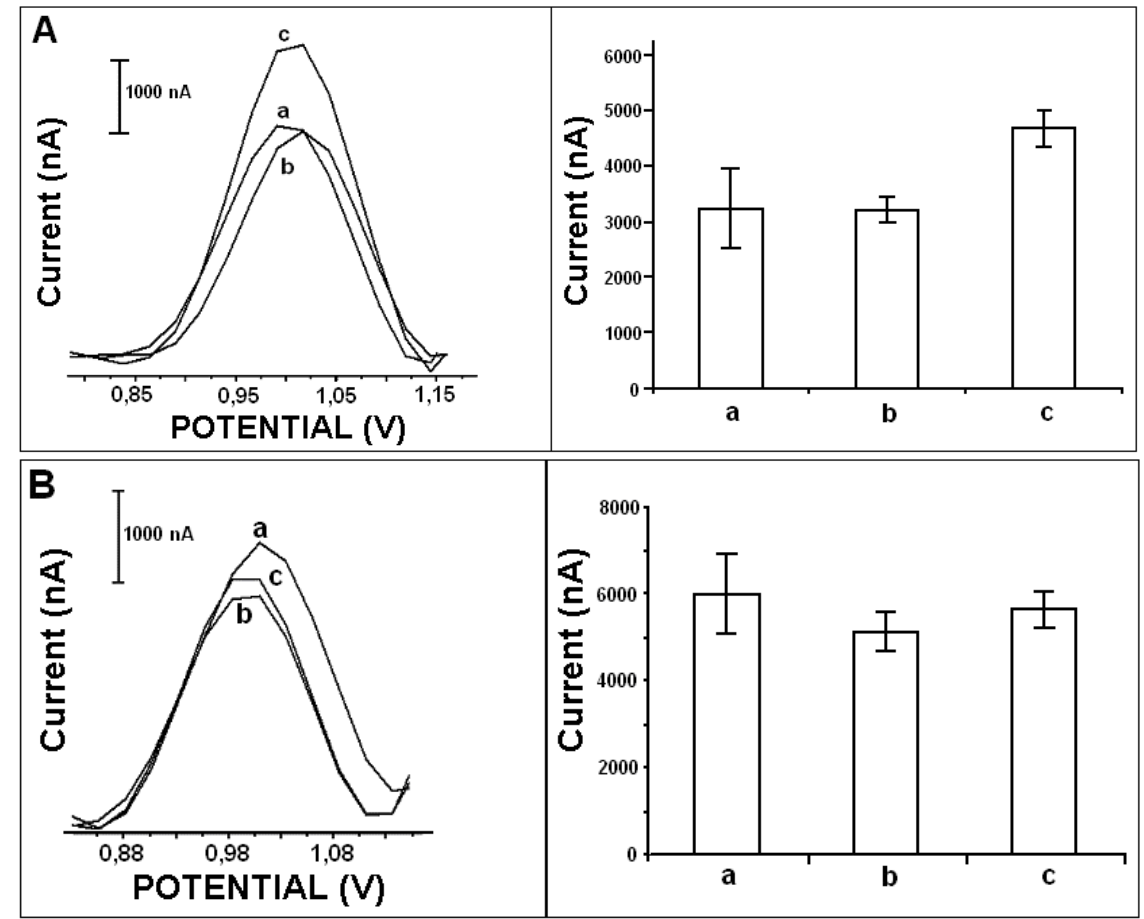

Figure 2. Differential pulse voltammograms and histograms representing the guanine oxidation signal obtained after $30 \mathrm{~min}$ interaction in different concentrations of LMZ and $50 \mu \mathrm{g} / \mathrm{mL}$ of dsDNA at the surface of (A) bare PGE and (B) SWCNT-PGE; (a) 0, (b) 2, (c) $5 \mu \mathrm{g} / \mathrm{mL}$ of LMZ (n=3).

Then, the effect of interaction time of $2 \mu \mathrm{g} / \mathrm{mL}$ LMZ with $50 \mu \mathrm{g} / \mathrm{mL}$ DNA was studied by using SWCNT-PGE such as, 5, 15 and $30 \mathrm{~min}$ (Figure 3). The highest decrease at the guanine oxidation signal was measured at $30 \mathrm{~min}$ interaction time and then it was levelled off (not shown). The average guanine oxidation signal was measured $5998 \pm 805 \mathrm{nA}$ before interaction, and for the $30 \mathrm{~min}$ interaction time it was measured $5197 \pm 490 \mathrm{nA}$, which means there has been $14.7 \%$ decrease at the guanine oxidation signal after interaction for SWCNT-PGE. 


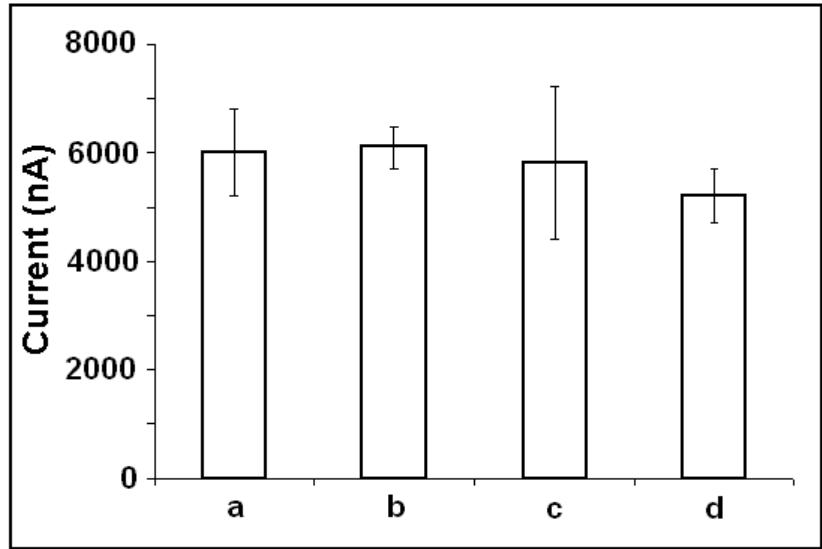

Figure 3. The histograms representing the guanine oxidation signal obtained after interaction of $2 \mu \mathrm{g} / \mathrm{mL}$ $\mathrm{LMZ}$ and $50 \mu \mathrm{g} / \mathrm{mL}$ of dsDNA in different interaction times such as, (a) 0, (b) 5, (c) 15 and (d) 30 min by using SWCNT-PGE $(\mathrm{n}=3)$.

Finally, the voltammetric results for the interaction study were also complemented with the ones investigated by electrochemical impedance spectroscopy (EIS), for the characterization of the successful construction of carbon nanotubes modification onto the surface of PGE. For this purpose, the $50 \mu \mathrm{g} / \mathrm{mL}$ fsDNA and 2 and $5 \mu \mathrm{g} / \mathrm{mL} \mathrm{LMZ} \mathrm{concentrations} \mathrm{were} \mathrm{used} \mathrm{for} \mathrm{interaction} \mathrm{study} \mathrm{by} \mathrm{using} \mathrm{EIS} \mathrm{(Figure} \mathrm{4).} \mathrm{The} \mathrm{average}$ $\mathrm{R}_{\mathrm{ct}}$ value was measured $8 \pm 3 \Omega$ for bare PGE (not shown), after the modification of the PGE surface with SWCNT, the average $R_{\mathrm{ct}}$ value was calculated as $49 \pm 13 \Omega$, which is six times larger than the one obtained by bare PGE. The change of the $\mathrm{R}_{\mathrm{ct}}$ value after modification was a strong proof that CNT had been immobilized on the PGE surface. After $50 \mu \mathrm{g} / \mathrm{mL}$ fsDNA immobilization the $R_{\mathrm{ct}}$ value increased to $450 \pm 20 \Omega$, because, the negatively charged phosphate backbone of double stranded DNA prevented redox couple, $\left[\mathrm{Fe}(\mathrm{CN})_{6}\right]^{3-/ 4-}$ from reaching the electrode surface. These results clearly presented that the modification of carbon nanotubes onto the graphite surface improved the immobilization capacity of dsDNA. Similar to the voltammetric studies, after the interaction of LMZ with DNA, the $R_{\mathrm{ct}}$ values were decreased to $334 \pm 31$ ve $378 \pm 67 \Omega$ for 2 and 5 $\mu \mathrm{g} / \mathrm{mL} \mathrm{LMZ}$ concentrations, which means there has been $24.8 \%$ decrease at the $\mathrm{R}_{\mathrm{ct}}$ value for $2 \mu \mathrm{g} / \mathrm{mL} \mathrm{LMZ}$. This decrease observed at the $R_{c t}$ value may possibly indicate that there was a specific interaction of LMZ with DNA assembled on SWCNTs by the intercalation $[11,38]$.

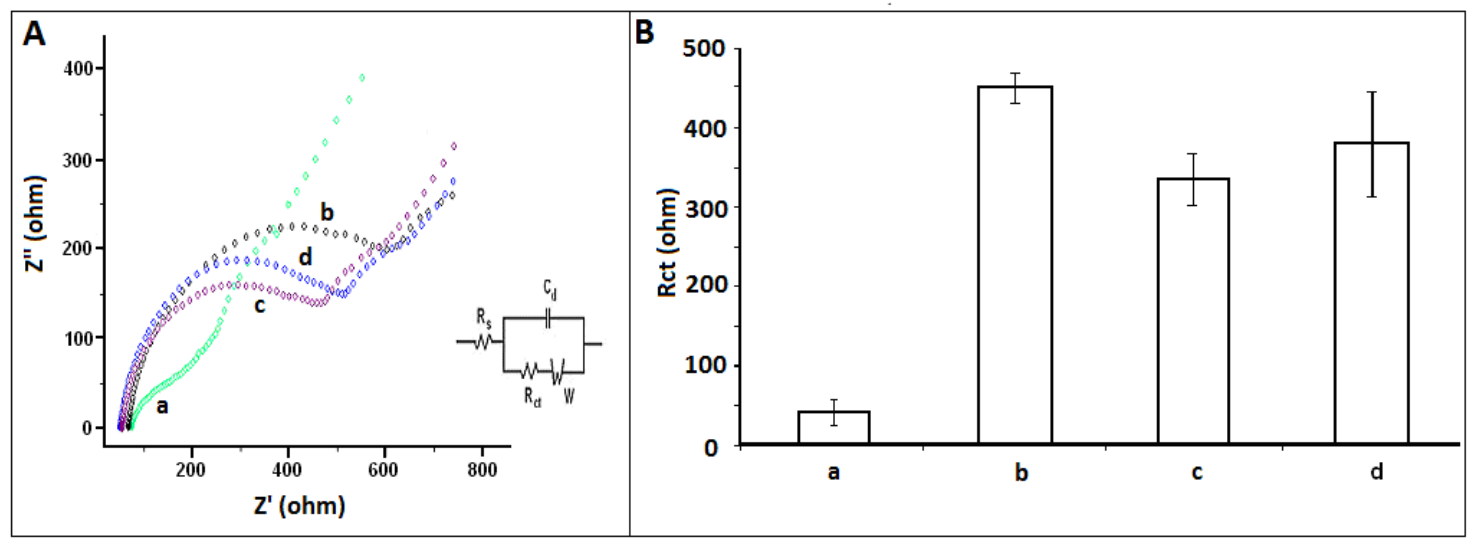

Figure 4. (A) Nyquist diagrams and (B) Histograms representing the Rct values, which recorded with supporting electrolyte solution $2.5 \mathrm{mM} \mathrm{K}_{3}\left[\mathrm{Fe}(\mathrm{CN})_{6}\right] / \mathrm{K}_{4}\left[\mathrm{Fe}(\mathrm{CN})_{6}\right](1: 1)$ containing, $0.1 \mathrm{M} \mathrm{KCl}$ by using (a) SWCNT modified PGE, (b) $50 \mu \mathrm{g} / \mathrm{mL}$ dsDNA immobilized CNT-PGE, after 30 min interaction of (c) 2 and (d) $5 \mu \mathrm{g} / \mathrm{mL}$ LMZ with dsDNA at the surface of SWCNT-PGE $(\mathrm{n}=3)$. Inset is the equivalent circuit model used to fit the impedance data, the parameters of which are: $R_{s}$ is the solution resistance, the constant phase element $C_{d}$ is related to the space charge capacitance at the DNA/electrolyte interface; $R_{c t}$ represents the charge transfer resistance at the DNA/electrolyte interface; the constant phase element W is the Warburg impedance due to mass transfer to the electrode surface. 


\section{CONCLUSION}

In this study, the reproducible and sensitive electrochemical detection of biomolecular interaction between LMZ and dsDNA by the advantages of SWCNTs modified PGE resulting with an enhancement at the guanine signal. There was not any report in the literature for electrochemical investigation of interaction between LMZ and dsDNA using CNT modified electrodes. Voltammetric results were consistent with the ones of electrochemical impedance spectroscopy. DPV and EIS results showed that DNA could be immobilized onto the surface of SWCNTs modified electrodes and after the interaction between LMZ and dsDNA, the signals were decreased.

Disposable CNT modified PGEs bring some important advantages to our assay including easy use, cost effectiveness and giving a response in a shorter time comparison to earlier studies performed by unmodified PGE [38] and carbon paste electrode [7] applied for electrochemical monitoring of drug-DNA interactions.

As a conclusion, the improved sensitivity of these disposable electrodes has a great importance for further development of carbon nanotube based electrochemical sensors, that may also be used for monitoring of different biomolecular interactions.

\section{MATERIALS AND METHODS}

\subsection{Apparatus}

All voltammetric measurements were performed by using AUTOLAB - PGSTAT 302 (Eco Chemie, The Netherlands) with GPES 4.9.007 software. The electrochemical impedance spectroscopy (EIS) measurements were performed by using IVIUM COMPACTSTAT with 1.918 software. The EIS measurements were done in the Faraday cage. The three electrode systems were used in all measurements which was consisted of a platinum wire as the auxiliary electrode, an $\mathrm{Ag} / \mathrm{AgCl} / \mathrm{KCl}$ reference electrode and the pencil graphite electrode (PGE) as the working electrode.

\subsection{Chemicals}

The fish sperm DNA stock solution DNA (dsDNA) was prepared with Tris-EDTA buffer (TE buffer; 10 $\mathrm{mM}$ Tris- $\mathrm{HCl}, 1 \mathrm{mM}$ EDTA, $\mathrm{pH} 8.00)$. All the dilute solutions of DNA were prepared with $0.50 \mathrm{M}$ acetate buffer containing $20 \mathrm{mM} \mathrm{NaCl}$ (pH 4.80, ABS). The LMZ stock solution was prepared with Tris buffer solution (TBS; $50 \mathrm{mM}$ Tris- $\mathrm{HCl}, 20 \mathrm{mM} \mathrm{NaCl}$ ). Single-walled carbon nanotubes (SWCNT) which were carboxylic acid (80 90\%) functionalized (diameter $4-5 \mathrm{~nm}$; length $500-1500 \mathrm{~nm}$ ) was purchased from Aldrich. All the other chemicals were supplied from Sigma and Merck.

\subsection{Preparation of CNT solution}

Carbon nanotubes were suspended in $\mathrm{N}, \mathrm{N}$-dimethylformamide (DMF) solution and then sonicated during a hour in the room temperature.

\subsection{Electrochemical detection procedure}

All the experiments were done at least three times, and the average values were presented in the histograms with the error bars. In all measurements, a new PGE was used for the electrochemical detection of drug -DNA interaction process. Each unpreated PGE was immersed into the $110 \mu \mathrm{L}$ of CNT solution during 1 hour according to the wet-adsorption procedure to form the CNT layer on the PGE surface. Each of the PGEs was rinsed with ABS for 3 times, and then CNT-PGEs were dried for $10 \mathrm{~min}$. The CNT-PGEs were immersed into the dsDNA solution in ABS during 1 hour. Then, each of the PGEs was rinsed with ABS for 3 times in order to remove unbound DNAs. DNA immobilized CNT modified PGEs (DNA-CNT-PGE) were immersed into the $110 \mu \mathrm{L}$ LMZ solution which was prepared in TBS. After 30 minutes, each PGEs was rinsed with TBS for 3 times. After the interaction process at the electrode surface, the DPV measurements was done in ABS. The measurement conditions were; scanning from +0.20 to $+1.45 \mathrm{~V}$ with $50 \mathrm{mV}$ pulse amplitude, and $30 \mathrm{mV} / \mathrm{s}$ scan rate.

\subsection{Impedance Measurements}

The EIS measurements were performed in of $2.5 \mathrm{mM} \mathrm{K}_{3}\left[\mathrm{Fe}(\mathrm{CN})_{6}\right] / \mathrm{K}_{4}\left[\mathrm{Fe}(\mathrm{CN})_{6}\right](1: 1)$ solution which was prepared in $0.1 \mathrm{M} \mathrm{KCl}$. The frequency range of impedance measurements was from $100 \mathrm{kHz}$ to $100 \mathrm{mHz}$ by applying $+0.23 \mathrm{~V}$ versus $\mathrm{Ag} / \mathrm{AgCl}($ sat. $\mathrm{KCl}$ ), with a sinusoidal signal of $10 \mathrm{mV}$. The frequency range were divided into 98 logarithmically collateral measure points. The charge-transfer resistance $\left(R_{\mathrm{ct}}\right)$ values which 
were corresponding the semicircle diameter, was calculated using the fitting program IVIUM COMPACTSTAT 1.918 software package.

Acknowledgements: Hakan Karadeniz acknowledges the financial support from Ege University Scientific Research Project Coordination (Project No. 10/ECZ/025).

Author contributions: Concept - H.K., A.E.; Design - H.K., A.E.; Supervision - A.E.; Resource - H.K., A.E.; Materials H.K., A.E.; Data Collection and/or Processing - H.K., E.E., A.E; Analysis and/or Interpretation - H.K., E.E.; A.E.; Literature Search - H.K., A.E.; Writing - H.K., A.E.; Critical Reviews - H.K., E.E., A.E.

Conflict of interest statement: The authors declared no conflict of interest in the manuscript.

\section{REFERENCES}

[1] Wang J. From DNA biosensors to gene chips. Nucl Acids Res. 2000; 28: 3011-3016. [CrossRef]

[2] Palecek E, Fojta M. Detecting DNA hybridization and damage. Anal Chem. 2001; 73: 75A-83A. [CrossRef]

[3] Erdem A. Nanomaterial-based electrochemical DNA sensing strategies. Talanta. 2007; 74: 318-325. [CrossRef]

[4] Kuralay F, Karadeniz H, Muti M, Erdem A. Electrochemical DNA detection using carbon nanotubes. Curr Physical Chem. 2011; 1: 325-333. [CrossRef]

[5] Erdem A, Ozsoz M. Electrochemical DNA Biosensors based on DNA-Drug Interactions. Electroanalysis. 2002; 14: 965-974. [CrossRef]

[6] Karadeniz H, Alparslan L, Erdem A, Karasulu E. Electrochemical investigation of interaction between Mitomycin C and DNA in a novel drug-delivery system. J Pharm Biomed Anal. 2007; 45: 322-326. [CrossRef]

[7] Wang J, Ozsoz M, Cai X, Rivas G, Shiraishi H, Grant DH, Chicharro M, Fernandes J, Palecek E . Interactions of antitumor drug daunomycin with DNA in solution and at the surface. Bioelectrochem Bioenerg. 1998; 45: 33-40. [CrossRef]

[8] Palecek E. From polarography of DNA to microanalysis with nucleic acid-modified electrodes. Electroanalysis. 1996; 8: 7-14. [CrossRef]

[9] Marin D, Perez P, Teijeiro C, Palecek E. Interactions of surface-confined DNA with acid-activated mitomycin C. Biophys Chem. 1998; 75: 87-95. [CrossRef]

[10] Oliveira Brett AM, Macedo TRA, Raimundo D, Marques MH, Serrano SHP. Voltammetric behaviour of mitoxantrone at a DNA-biosensor. Biosens Bioelectron. 1998; 13: 861-867. [CrossRef

[11] Erdem A, Muti M, Papakonstantinou P, Canavar E, Karadeniz H, Congur G, Sharma S. Graphene oxide integrated sensor for electrochemical monitoring of mitomycin C-DNA interaction. Analyst. 2012; 137: 2129-2135. [CrossRef]

[12] Ribeiro JA, Pereira CM, Silva F. Electrochemistry of the interaction between bioactive drugs Daunorubicin and Dopamine and DNA at a water/oil interface. Electrochim Acta. 2015; 180: 687-694. [CrossRef]

[13] Shervedani RK, Mirhosseini H, Foroushani MS, Torabi M, Rahsepar FR, Barough LN. Immobilization of methotrexate anticancer drug onto the graphene surface and interaction with calf thymus DNA and 4T1 cancer cells. Bioelectrochemistry. 2018; 119: 1-9. [CrossRef]

[14] Erdem A, Ozsoz M. Interaction of the anticancer drug epirubicin with DNA. Anal Chim Acta. 2001; 437: 107-114. [CrossRef]

[15] Wang J. Carbon-nanotube based electrochemical biosensors: A review. Electroanalysis. 2005; 17: 7-14. [CrossRef]

[16] lijima S. Helical microtubules of graphitic carbon. Nature. 1991; 354: 56-58. [CrossRef]

[17] Erdem A, Papakonstantinou P, Murphy H. Direct DNA hybridization at disposable graphite electrodes modified with carbon nanotubes. Anal Chem. 2006; 78: 6656-6659. [CrossRef]

[18] Campidelli S, Klumpp C, Bianco A, Guldi DM, Prato M. Functionalization of CNT: Synthesis and applications in photovoltaics and biology. J Phys Org Chem. 2006; 19: 531-539. [CrossRef]

[19] Britto PJ, Santhanam KSV, Ajayan PM. Carbon nanotube electrode for oxidation of dopamine. Bioelectrochem Bioenerg. 1996; 41: 121-125. [CrossRef]

[20] Erdem A, Papakonstantinou P, Murphy H. Direct DNA hybridization at disposable graphite electrodes modified with carbon nanotubes. Anal Chem. 2006; 78: 6656-6659. [CrossRef] 
[21] Erdem A, Karadeniz H, Caliskan A. Single-walled carbon nanotubes modified graphite electrodes for electrochemical monitoring of nucleic acids and biomolecular interactions. Electroanalysis. 2009; 21: 464-471. [CrossRef]

[22] Caliskan A, Erdem A, Karadeniz H. Direct DNA hybridization on the single-walled carbon nanotubes modified sensors detected by voltammetry and electrochemical impedance spectroscopy. Electroanalysis. 2009; 21: 2116-2124. [CrossRef]

[23] Karadeniz H, Erdem A, Caliskan A. Electrochemical monitoring of DNA hybridization by multi-walled carbon nanotube based screen printed electrodes. Electroanalysis. 2008; 20: 1932-1938. [CrossRef]

[24] Willner I, Willner B. Biomolecule-based nanomaterials and nanostructures. Nano Lett. 2010; 10: 3805-3815. [CrossRef]

[25] Vega D, Agüi L, Gonzalez-Cortes A, Yanez-Sedeno P, Pingarron JM. Electrochemical detection of phenolic estrogenic compounds at carbon nanotube-modified electrodes. Talanta. 2007; 71: 1031-1038. [CrossRef]

[26] Banks CE, Davies TJ, Wildgoose GG, Compton RG. Electrocatalysis at graphite and carbon nanotube modified electrodes: edge-plane sites and tube ends are the reactive sites. Chem Commun. 2005; 7: 829-841. [CrossRef]

[27] Denofrio MP, Thomas AH, Braun AM, Oliveros E, Lorente C. Photochemical and photophysical properties of lumazine in aqueous solutions. J Photochem Photobiol. 2008; 200: 282-286. [CrossRef]

[28] Rembold H, Gyure WL. Biochemistry of the pteridines. Angew Chem Int Ed. 1972; 11: 1061-1072. [CrossRef]

[29] Faria PA, Chen X, Lombardi JR, Birke RL. A surface-enhanced Raman and ab initio study of spectra of lumazine molecules. Langmuir 2000; 16: 3984-3992. [CrossRef]

[30] Lehnen J, White BM, Kendrick MJ. Electrochemical studies of biologically significant pterin compounds. Inorg Chim Acta. 1990; 167: 257-259. [CrossRef]

[31] Nagar-Anthal KR, Worrell VE, Teal R, Nagle DP. The pterin lumazine inhibits growth of methanogens and methane formation. Arch Microbiol. 1996; 166: 136-140. [CrossRef]

[32] He RX, Zha DW. Cyclic voltammetry and voltabsorptometry studies of redox mechanism of lumazine. J Electroanal Chem. 2017; 791: 103-108. [CrossRef]

[33] Diculescu VC, Militaru A, Shah A, Qureshi R, Tugulea L, Brett AMO. Redox mechanism of lumazine at a glassy carbon electrode. J Electroanal Chem. 2010; 647(1): 1-7. [CrossRef]

[34] Ibrahim MS, Shehatta IS, Al-Nayeli AA. Voltammetric studies of the interaction of lumazine with cyclodextrins and DNA. J Pharm Biomed Anal. 2002; 28(2); 217-225. [CrossRef]

[35] Ibrahim MS. Phase-selective a.c. adsorptive stripping voltammetry of lumazine on a hanging mercury drop electrode. Fresenius' J Anal Chem. 2000; 367(2); 189-194. [CrossRef]

[36] Erdem A, Karadeniz H, Caliskan A. Single-walled carbon nanotubes modified graphite electrodes for electrochemical monitoring of nucleic acids and biomoleculer interactions. Electroanalysis. 2009; 21: 464-471. [CrossRef]

[37] Yang K, Zhang C. Simple detection of nucleic acids with a single-walled carbon-nanotubes-based electrochemical biosensor. Biosens Bioelectron. 2011; 28: 257-262. [CrossRef]

[38] Karadeniz H, Alparslan L, Erdem A, Karasulu E. Electrochemical investigation of interaction between mitomycin C and DNA in a novel drug-delivery system. J Pharm Biomed Anal. 2007; 45; 322-326. [CrossRef]

This is an open access article which is publicly available on our journal's website under Institutional Repository at http://dspace.marmara.edu.tr. 